\title{
INFLUENCE OF DIETARY THREONINE AND TRYPTOPHAN SUPPLEMENTATIONS ON BROILER PRODUCTIVITY TRAITS UNDER EGYPTIAN SUMMER CONDITIONS
}

\author{
Helal $^{1 *}$ A.A., Abdel-Azeem ${ }^{1}$ F., Thabet $^{1}$ H.A. and ELBaz ${ }^{2}$ A.M. \\ 1-Poultry Production Dept., Fac. of Agric., Ain Shams Univ., P.O. Box 68, Hadayek Shoubra \\ 11241, Cairo, Egypt. \\ 2- Nutrition poultry Dept., Desert Research Center, Mataria, Cairo, Egypt.
}

*Corresponding author: amradel2200@yahoo.com

Received 27 May, 2020

Accepted 23 August, 2020

\section{ABSTRACT}

A study was conducted to investigate the effects of feeding different levels of threonine and tryptophan on growth performance, some serum parameters and carcass traits of broiler chicks under Egyptian summer conditions. Three hundred and sixty Ross 308, one-day-old broiler chicks were randomly allocated into nine treatments with 4 replicates of 10 chicks each. Three levels of threonine $(100,150$ or $200 \%$ ) and three levels of tryptophan (100, 150 or $200 \%$ ) according to dietary requirements for Ross 308 chick's guidebook were used in a factorial design arrangement to obtain nine experimental treatments. Two periodical diets were used (starter phase 1-21 days and grower phase 22-35 days). Growth performance traits including live body weight (LBW), Body weight gain (BWG), feed consumption (FC) and feed conversion ratio (FCR) were recorded at the end of each week. Carcasses were manually eviscerated and weighed. Components of total protein, albumin, cholesterol, and triglycerides were analyzed by using commercial kits. The results showed that chicks fed diet containing $200 \%$ threonine had an improvement in live body weight, body weight gain and feed conversion ratio. The performance index increased with the addition of threonine and tryptophan in the broiler diets. Serum total protein and globulin concentrations were affected by supplemental threonine and tryptophan. Dietary threonine, tryptophan did not affect serum albumin and triglycerides. Total cholesterol was increased with supplementation of threonine, tryptophan and interaction between them. Chicks fed $100 \%$ dietary threonine had the significantly better results in terms of the relative weights of carcass,
\end{abstract}

edible parts and bursa compared to the chicks fed other dietary threonine levels, although tryptophan amino acid had not any significant effect on the above-mentioned traits. Giblets, liver, and heart weights percentage increase with increasing tryptophan level in the broiler diets. The relative weight of gizzard reduced with increasing level of both amino acids in the diets.

In this study, it concluded that supplementation of threonine and tryptophan improves productive performance and health status of broiler chicks without imposing any toxicity as all blood components were in normal range.

Keywords: Broilers, Performance, Threonine, Tryptophan, Blood, Carcass

\section{INTRODUCTION}

High ambient temperature constitutes a significant hindrance for poultry production in the tropical world. Thermal stress exerts its deleterious effects on feed intake and body weight gain (Tabiri et al 2002). Protein is consists of a group of amino acids that play an important role in the biological processes such as intervention in the composition of antibodies that are essential in the immune system and regulators of metabolism pathways within organisms (Wu, 2009). In recent studies, using synthesized amino acids to meet the requirements of broiler chicks to enhance productive performance is more adapted. Tryptophan and threonine are the most critical amino acids for broiler chicks after methionine and lysine to maintain the balance of the diet and meet the requirements of the broilers. Threonine (Thr) is vital for protein synthesis and maintenance across the bird body moreover it contains 
about $11.7 \%$ nitrogen (Kidd and Kerr, 1996). Age of birds, crude protein $\%$ and diet ingredients are the most essential factors that affecting threonine requirements (Barkley and Wallis, 2001). The recommended levels of NRC (1994) for total threonine were $0.80 \%$ in the starter phase, $0.74 \%$ in the grower phase, and $0.68 \%$ in the finisher phase. Lately, Najafi et al (2017) study the effects of feeding different levels of threonine on growth performance in broilers during starter phase $(0.89,0.93$ and $0.97 \%$ ) with $0.65 \%$ as a control diet, they found that the broilers fed $0.97 \%$ of threonine showed feed intake higher by $5.1 \%$, body weight gain higher by $6.4 \%$ and FCR better by $1.4 \%$ than control birds. Carlstedt et al (1993) and Corzo et al (2007) reported that threonine is an important fraction of mucus in the GIT, where the protein of mucus glycoproteins is about $40 \%$ threonine along with threonine plays an important role in the regulation of fat metabolism, promoting the function of the immune response system and bone formation (Qaisrani et al 2018). Threonine is a precursor of glycine and serine (Lemme, 2003). Elevating the concentration of dietary threonine might enhance the growth of immune organs, motivate antibody synthesis, and reduce the immune stress caused by $E$. coli challenge or (ND) virus (Azzam et al 2012; Trevisi et al 2015).

Tryptophan (Trp) is an important component for protein formation as well as a precursor for important hormones such as serotonin and melatonin that plays an essential role in sustaining normal physiological processes, such as, tissue protein synthesis, growth performance, feed efficiency and immune response in broiler chickens (Bai et al 2017). Also, Trp is promoting the production of niacin, which improves FCR and increase growth performance (Richard et al 2009; Hoseini et al 2019; Apolla et al 2017). Serotonin is a neurotransmitter that ameliorates the climatic adaptability and allays oxidative stress (Martin et al 2000). The deficiency of Trp causes a reduction in body weight gain, decreased feed intake and deteriorated feed conversion ratio (FCR) as well as compromised antibody status (Mozhdeh et al 2010). On the other hand, Gogary and Azzam (2014) reported that increasing dietary levels of L-Trp does not affect on BW, BWG and FCR. Conversely, feed intake decreased significantly. The present study was designed to investigate the effects of different dietary levels of tryptophan and threonine on growth performance, some serum components and carcass traits of broiler chicks under Egyptian summer conditions.

\section{MATERIALS AND METHODS}

The current study was carried out at the Poultry Nutrition Experimental Farm, Poultry Production Department, Faculty of Agriculture, Ain Shams University, Shoubra El-kheima, Egypt. A total number of 360 Ross 308 , one-day-old broiler chicks were randomly allocated into nine treatments with 4 replicates (10 birds each). Dietary treatments consisted of three levels of tryptophan (100, 150 and $200 \%$ of the dietary requirements) with three levels of threonine $(100,150$ and $200 \%$ of the dietary requirements) to obtain nine treatments in factorial arrangement design. Periodical diets were formulated to ensure enough supply of nutrients suggested by the guidebook of Ross 308 broilers to be isocaloric and isonitrogenous and were offered in mash form (Table 1 and 2). The chicks reared in a temperature range from 25 to $36^{\circ} \mathrm{C}$ during the experimental period. All birds were vaccinated by drinking-waterbased vaccination against Newcastle disease by Hitchner B1 at the age of 7 days and Lasota twice at 18 and 28 days, also vaccinated against Gumboro at 14 days. Live body weight (LBW) of the chicks was recorded weekly in grams; the average body weight gain (ABWG) was individually calculated. Average feed consumption (AFC) was recorded weekly and feed conversion ratio (FCR, $g$ feed /g gain) was calculated. Performance index (live body weight $(\mathrm{kg})$ / feed conversion ratio $\times 100$ ) was calculated according to North (1981). At five weeks of age, eight chicks from each experimental treatment group were randomly chosen, weighed and slaughtered by cutting the jugular vein, then scalded and defeathered. Carcasses were manually eviscerated and weighed. The liver, heart, gizzard, intestine and abdominal fat were weighed and calculated as a percentage of live weight. Blood samples were collected at slaughtering in heparinized glass tubes (8 samples per each treatment group). Blood plasma was separated by centrifugation at $3000 \mathrm{rpm}$ for 15 minutes. The collected plasma was stored at $-20^{\circ} \mathrm{C}$ until assay. The biochemical analyses of total protein, albumin, cholesterol, and triglycerides were performed at poultry department laboratories, Faculty of Agriculture, Ain Shams University by using commercial kits. The globulin values were obtained by subtracting the values of albumin from the corresponding values of total proteins. A: $G$ ratio was calculated by dividing the value of albumin on the value of globulin. The values were analyzed statistically using a two-way analysis of variance method according to SAS (1998). Duncan's new Multiple Range procedure was followed 


\section{Influence of dietary threonine and tryptophan supplementations on}

broiler productivity traits under Egyptian summer conditions

to separate means (Duncan, 1955). The model applied was: $Y_{i j k}=\mu+T_{i}+P_{j}+\left(T^{*} P\right)_{i j}+E_{i j k}$ Where: $Y_{i j k}=o b-$ servation of the parameter measured, $\mu=$ overall mean, the $T_{i}=$ effect of threonine supplementation,
$\mathrm{P}_{\mathrm{j}}=$ effect of tryptophan supplementation, $\left(\mathrm{T}^{\star} \mathrm{P}\right)_{\mathrm{ij}=}$ the interaction between dietary threonine and tryptophan effect., $\mathrm{E}_{\mathrm{ijk}}=$ random error effect.

Table 1. Feed ingredients and calculated chemical composition of experimental diets during starter phase

\begin{tabular}{|c|c|c|c|c|c|c|c|c|c|}
\hline Ingredients & $\begin{array}{l}100 \mathrm{~T} / \\
100 \mathrm{P}\end{array}$ & $\begin{array}{l}100 \mathrm{~T} / \\
150 \mathrm{P}\end{array}$ & $\begin{array}{l}100 \mathrm{~T} / \\
200 \mathrm{P}\end{array}$ & $\begin{array}{l}150 \mathrm{~T} / \\
100 \mathrm{P}\end{array}$ & $\begin{array}{l}150 \mathrm{~T} / \\
150 \mathrm{P}\end{array}$ & $\begin{array}{l}150 \mathrm{~T} / \\
200 \mathrm{P}\end{array}$ & $\begin{array}{l}200 \mathrm{~T} / \\
100 \mathrm{P}\end{array}$ & $\begin{array}{l}200 \mathrm{~T} / \\
150 \mathrm{P}\end{array}$ & $\begin{array}{l}200 T / \\
200 \mathrm{P}\end{array}$ \\
\hline Yellow Corn & 59.38 & 59.38 & 59.38 & 59.38 & 59.38 & 59.38 & 59.38 & 59.38 & 59.38 \\
\hline Soybean meal $48 \%$ & 21.22 & 21.22 & 21.22 & 21.22 & 21.22 & 21.22 & 21.22 & 21.22 & 21.22 \\
\hline Corn Gluten $60 \%$ & 11.70 & 11.70 & 11.70 & 11.70 & 11.70 & 11.70 & 11.70 & 11.70 & 11.70 \\
\hline Vegetable Oil & 1.00 & 1.00 & 1.00 & 1.00 & 1.00 & 1.00 & 1.00 & 1.00 & 1.00 \\
\hline Ca Carbonate & 1.00 & 1.00 & 1.00 & 1.00 & 1.00 & 1.00 & 1.00 & 1.00 & 1.00 \\
\hline Di Ca Phosphate & 1.80 & 1.80 & 1.80 & 1.80 & 1.80 & 1.80 & 1.80 & 1.80 & 1.80 \\
\hline Sand & 2.40 & 2.28 & 2.17 & 1.92 & 1.80 & 1.69 & 1.44 & 1.32 & 1.21 \\
\hline $\mathrm{HCl}-$ Lysine & 0.54 & 0.54 & 0.54 & 0.54 & 0.54 & 0.54 & 0.54 & 0.54 & 0.54 \\
\hline DL-Methionine & 0.22 & 0.22 & 0.22 & 0.22 & 0.22 & 0.22 & 0.22 & 0.22 & 0.22 \\
\hline Salt $(\mathrm{NaCl})$ & 0.20 & 0.20 & 0.20 & 0.20 & 0.20 & 0.20 & 0.20 & 0.20 & 0.20 \\
\hline Tryptophan & 0.00 & 0.12 & 0.23 & 0.00 & 0.12 & 0.23 & 0.00 & 0.12 & 0.23 \\
\hline Threonine & 0.06 & 0.06 & 0.06 & 0.54 & 0.54 & 0.54 & 1.02 & 1.02 & 1.02 \\
\hline Choline & 0.18 & 0.18 & 0.18 & 0.18 & 0.18 & 0.18 & 0.18 & 0.18 & 0.18 \\
\hline Premix ${ }^{\#}$ & 0.30 & 0.30 & 0.30 & 0.30 & 0.30 & 0.30 & 0.30 & 0.30 & 0.30 \\
\hline Total & 100.00 & 100.00 & 100.00 & 100.00 & 100.00 & 100.00 & 100.00 & 100.00 & 100.00 \\
\hline \multicolumn{10}{|c|}{ Calculated chemical composition } \\
\hline Crude protein (CP \%) & 22.98 & 22.98 & 22.98 & 22.97 & 22.97 & 22.97 & 23.00 & 23.00 & 23.00 \\
\hline $\mathrm{ME}(\mathrm{Kcal} / \mathrm{kg})$ & 3007 & 3007 & 3007 & 3007 & 3007 & 3007 & 3020 & 3020 & 3020 \\
\hline Calcium (\%) & 0.954 & 0.954 & 0.954 & 0.954 & 0.954 & 0.954 & 0.962 & 0.962 & 0.962 \\
\hline A. phosphorous $\%$ & 0.483 & 0.483 & 0.483 & 0.483 & 0.483 & 0.483 & 0.482 & 0.482 & 0.482 \\
\hline DL-Methionine & 0.687 & 0.687 & 0.687 & 0.687 & 0.687 & 0.687 & 0.653 & 0.653 & 0.653 \\
\hline $\mathrm{METH}+\mathrm{CYS}$ & 1.079 & 1.079 & 1.079 & 1.079 & 1.079 & 1.079 & 1.047 & 1.047 & 1.047 \\
\hline Lysine & 1.450 & 1.450 & 1.450 & 1.450 & 1.450 & 1.450 & 1.442 & 1.442 & 1.442 \\
\hline Threonine & 0.98 & 0.98 & 0.98 & 1.455 & 1.455 & 1.455 & 1.93 & 1.93 & 1.93 \\
\hline Tryptophan & 0.23 & 0.35 & 0.46 & 0.23 & 0.35 & 0.46 & 0.23 & 0.35 & 0.46 \\
\hline
\end{tabular}

\# Each $3 \mathrm{Kg}$ of the premix contain: Vitamins: A: $15000000 \mathrm{lU}$; Vit. D3 $2000000 \mathrm{IU} ; \mathrm{E}: 50 \mathrm{~g} ; \mathrm{K}_{3}: 3000 \mathrm{mg} ; \mathrm{B}_{1}: 3000$ mg; $\mathrm{B}_{2}$ : 8000 mg; $B_{6}: 4000$ mg; B $12: 20$ mg; Biotin: 200 mg; Choline chloride: 700 mg; Pantothenic acid: 200000 mg; Nicotinic acid: 60000 mg; Folic acid: 1500 mg; Minerals: Mn: 80 g; Zn: 80 g; Fe: 60 g; Cu: 10 g; I: 1 g; and Se: 0.2 g, and $\mathrm{CaCO}_{3}$ as a carrier up to $3 \mathrm{Kg} .100,150,200 \mathrm{~T}=$ Threonine supplementation, 100, 150, $200 \mathrm{P}=$ Tryptophan supplementation 
Table 2. Feed ingredients and chemical composition of experimental diets during grower phase

\begin{tabular}{|c|c|c|c|c|c|c|c|c|c|}
\hline Ingredient & $\begin{array}{l}100 \mathrm{~T} / \\
100 \mathrm{P}\end{array}$ & $\begin{array}{l}100 \mathrm{~T} / \\
150 \mathrm{P}\end{array}$ & $\begin{array}{l}100 \mathrm{~T} / \\
200 \mathrm{P}\end{array}$ & $\begin{array}{l}150 \mathrm{~T} / \\
100 \mathrm{P}\end{array}$ & $\begin{array}{l}150 \mathrm{~T} / \\
150 \mathrm{P}\end{array}$ & $\begin{array}{l}150 \mathrm{~T} / \\
200 \mathrm{P}\end{array}$ & $\begin{array}{l}200 \mathrm{~T} / \\
100 \mathrm{P}\end{array}$ & $\begin{array}{l}200 \mathrm{~T} / \\
150 \mathrm{P}\end{array}$ & $\begin{array}{l}200 \mathrm{~T} / \\
200 \mathrm{P}\end{array}$ \\
\hline Yellow Corn & 62.90 & 62.90 & 62.90 & 63.36 & 63.47 & 63.57 & 63.81 & 63.92 & 64.02 \\
\hline Soy $48 \%$ & 18.00 & 18.00 & 18.00 & 18.00 & 18.00 & 18.00 & 18.00 & 18.00 & 18.00 \\
\hline Corn Gluten $60 \%$ & 11.50 & 11.50 & 11.50 & 11.50 & 11.50 & 11.50 & 11.50 & 11.50 & 11.50 \\
\hline Vegetable Oil & 1.62 & 1.62 & 1.62 & 1.62 & 1.62 & 1.62 & 1.62 & 1.62 & 1.62 \\
\hline Ca Carbonate & 1.00 & 1.00 & 1.00 & 1.00 & 1.00 & 1.00 & 1.00 & 1.00 & 1.00 \\
\hline Di Ca Phosphate & 1.55 & 1.55 & 1.55 & 1.55 & 1.55 & 1.55 & 1.55 & 1.55 & 1.55 \\
\hline Sand & 2.07 & 1.98 & 1.88 & 1.63 & 1.52 & 1.42 & 1.18 & 1.07 & 0.97 \\
\hline $\mathrm{HCl}-$ Lysine & 0.50 & 0.50 & 0.50 & 0.50 & 0.50 & 0.50 & 0.50 & 0.50 & 0.50 \\
\hline DL-Methionine & 0.18 & 0.18 & 0.18 & 0.18 & 0.18 & 0.18 & 0.18 & 0.18 & 0.18 \\
\hline Salt $(\mathrm{NaCl})$ & 0.20 & 0.20 & 0.20 & 0.20 & 0.20 & 0.20 & 0.20 & 0.20 & 0.20 \\
\hline Tryptophan & 0.00 & 0.11 & 0.21 & 0.00 & 0.11 & 0.21 & 0.00 & 0.11 & 0.21 \\
\hline Threonine & 0.02 & 0.02 & 0.02 & 0.46 & 0.46 & 0.46 & 0.91 & 0.91 & 0.91 \\
\hline Choline & 0.16 & 0.16 & 0.16 & 0.16 & 0.16 & 0.16 & 0.16 & 0.16 & 0.16 \\
\hline Premix & 0.30 & 0.30 & 0.30 & 0.30 & 0.30 & 0.30 & 0.30 & 0.30 & 0.30 \\
\hline Total & 100.00 & 100.00 & 100.00 & 100.00 & 100.00 & 100.00 & 100.00 & 100.00 & 100.00 \\
\hline \multicolumn{10}{|c|}{ Calculated chemical composition } \\
\hline Crude protein (CP\%) & 21.55 & 21.55 & 21.55 & 21.53 & 21.53 & 21.53 & 21.56 & 21.56 & 21.56 \\
\hline ME (Kcal/kg) & 3101 & 3101 & 3101 & 3094 & 3094 & 3094 & 3108 & 3108 & 3108 \\
\hline Calcium (\%) & 0.877 & 0.877 & 0.877 & 0.877 & 0.877 & 0.877 & 0.876 & 0.876 & 0.876 \\
\hline A. phosphorous $\%$ & $0 . .431$ & $0 . .431$ & $0 . .431$ & 0.431 & 0.431 & 0.431 & 0.432 & 0.432 & 0.432 \\
\hline DL-Methionine & 0.627 & 0.627 & 0.627 & 0.627 & 0.627 & 0.627 & 0.628 & 0.628 & 0.628 \\
\hline METH+CYS & 0.998 & 0.998 & 0.998 & 1.079 & 1.079 & 1.079 & 0.999 & 0.999 & 0.999 \\
\hline Lysine & 1.321 & 1.321 & 1.321 & 1.312 & 1.312 & 1.312 & 1.306 & 1.306 & 1.306 \\
\hline Threonine & 0.886 & 0.886 & 0.886 & 1.32 & 1.32 & 1.32 & 1.767 & 1.767 & 1.767 \\
\hline Tryptophan & 0.214 & 0.32 & 0.42 & 0.214 & 0.32 & 0.42 & 0.214 & 0.32 & 0.42 \\
\hline
\end{tabular}

\# Each $3 \mathrm{Kg}$ of the vitamins and minerals premix contain: Vitamins: A: $15000000 \mathrm{IU}$; Vit. D3 $2000000 \mathrm{IU} ; \mathrm{E}: 50 \mathrm{~g} ; \mathrm{K}_{3}: 3000$ mg; $B_{1}: 3000$ mg; $B_{2}: 8000$ mg; $B_{6}: 4000$ mg; $B_{12}: 20$ mg; Biotin: 200 mg; Choline chloride: 700 mg; Pantothenic acid: 200000 mg; Nicotinic acid: 60000 mg; Folic acid: 1500 mg; Minerals: Mn: 80 g; Zn: 80 g; Fe: 60 g; Cu: 10 g; I: 1 g; and Se: $0.2 \mathrm{~g}$, and $\mathrm{CaCO}_{3}$ as a carrier up to $3 \mathrm{Kg}$.

100, 150, $200 \mathrm{~T}$ = Threonine supplementation, 100, 150, $200 \mathrm{P}=$ Tryptophan supplementation

\section{RESULTS AND DISCUSSION}

\section{Productive performance}

Results indicated that threonine supplementation insignificantly improved LBW, ABWG, performance index and FCR in broilers fed diets supplemented with $200 \%$ threonine with different levels of tryptophan compared to other treatments (Table 3). Moghaddam et al (2011) reported that the addition of threonine in diets can improve performance for Ross (308) broilers, which is in harmony with our results. However, the results are in disagreement with Rama Rao et al (2011) who found that there was any difference in broiler performance fed diets supplemented with threonine. Many factors that may explain the different results obtained within re- searchers, such as the protein content of experimental diets, digestibility of amino acids, or environmental temperature (Zaghari et al 2011 and Shan et al 2003). The improved FCR was significantly associated with an increase in LBW in chicks fed with diet containing $200 \%$ of threonine, regardless of the concentration of tryptophan in the diet.

The results showed that broiler performance and feed intake were not affected by tryptophan content in the diet; these results are compatible with for a report by Hsia et al (2005). On the other hand, these results were in disagreement with those obtained by (Rosa et al 2001; Fatufe et al 2005 and Campos et al 2010). These authors reported that there was an improvement in broiler final body weight, which fed diets supplemented with high levels of tryptophan compared with the control group. 


\section{Influence of dietary threonine and tryptophan supplementations on}

broiler productivity traits under Egyptian summer conditions

Nevertheless, our observations in this study disagree with those reported by Waldroup et al (2005), who found that a balanced mixture of several amino acids may be more valuable compared with inclusion a single essential amino acid in the diet, the results may differ if dietary $\mathrm{CP}$ was reduced, the inclusion of the single amino acids might play an important role to support optimal growth performance. Tryptophan is the precursor for synthesis serotonin, which is a neurotransmitter that plays an important role in the regulation of increasing appetite and therefore feed intake (Harms and Russels 2000; Xi et al 2009). Birds fed tryptophan deficient diets exhibited a declined level of serotonin in the body which is directly associated with the reduced availability of tryptophan for serotonin biosynthesis thus resulting in appetite depression and decreased feed intake Emadi et al (2010).

Table 3. Effect of feeding different levels of Threonine and Tryptophan on productive performance of broiler chicks

\begin{tabular}{|c|c|c|c|c|c|c|c|c|c|}
\hline \multirow{2}{*}{ Items } & \multirow{2}{*}{$\begin{array}{l}\text { Threonine } \\
\text { levels }(T)\end{array}$} & \multicolumn{3}{|c|}{ Tryptophan Levels (P) } & \multirow{5}{*}{$\begin{array}{l}\text { Overall } \\
1543.50 \\
1554.49 \\
1581.40\end{array}$} & \multirow[t]{2}{*}{ SEM } & \multicolumn{3}{|c|}{ Prob } \\
\hline & & 100 & 150 & 200 & & & $\mathbf{T}$ & $\mathbf{P}$ & $T^{*} \mathbf{P}$ \\
\hline \multirow{4}{*}{ LBW } & 100 & 1536.63 & 1547.33 & 1546.54 & & \multirow{4}{*}{108.9} & \multirow{4}{*}{ NS } & \multirow{4}{*}{ NS } & \multirow{4}{*}{ NS } \\
\hline & 150 & 1568.46 & 1533.83 & 1561.17 & & & & & \\
\hline & 200 & 1575.00 & 1593.46 & 1575.75 & & & & & \\
\hline & Overall & 1560.03 & 1558.21 & 1561.15 & & & & & \\
\hline \multirow{4}{*}{ ABWG } & 100 & 1501.06 & 1511.53 & 1510.48 & 1507.69 & \multirow{4}{*}{108.8} & \multirow{4}{*}{ NS } & \multirow{4}{*}{ NS } & \multirow{4}{*}{ NS } \\
\hline & 150 & 1533.39 & 1498.07 & 1525.00 & 1518.82 & & & & \\
\hline & 200 & 1540.17 & 1556.76 & 1539.82 & 1545.58 & & & & \\
\hline & Overall & 1524.87 & 1522.12 & 1525.10 & & & & & \\
\hline \multirow[t]{4}{*}{ AFC } & 100 & 2526.3 & 2478.4 & 2438.5 & 2481.0 & \multirow{4}{*}{78.5} & \multirow{4}{*}{ NS } & \multirow{4}{*}{ NS } & \multirow{4}{*}{ NS } \\
\hline & 150 & 2642.5 & 2466.8 & 2446.9 & 2518.7 & & & & \\
\hline & 200 & 2495.9 & 2537.5 & 2471.4 & 2501.6 & & & & \\
\hline & Overall & 2554.9 & 2494.2 & 2452.2 & & & & & \\
\hline \multirow{4}{*}{ FCR } & 100 & 1.68 & 1.64 & 1.62 & 1.65 & \multirow{4}{*}{0.14} & \multirow{4}{*}{ NS } & \multirow{4}{*}{ NS } & \multirow{4}{*}{ NS } \\
\hline & 150 & 1.72 & 1.65 & 1.61 & 1.66 & & & & \\
\hline & 200 & 1.62 & 1.63 & 1.61 & 1.62 & & & & \\
\hline & Overall & 1.68 & 1.64 & 1.61 & & & & & \\
\hline \multirow{4}{*}{$\begin{array}{c}\text { Performance } \\
\text { index }\end{array}$} & 100 & 91.47 & 94.349 & 95.47 & 93.76 & \multirow{4}{*}{7.12} & \multirow{4}{*}{ NS } & \multirow{4}{*}{ NS } & \multirow{4}{*}{ NS } \\
\hline & 150 & 91.19 & 92.959 & 96.97 & 93.71 & & & & \\
\hline & 200 & 97.22 & 97.758 & 97.87 & 97.62 & & & & \\
\hline & Overall & 93.29 & 95.022 & 96.77 & & & & & \\
\hline
\end{tabular}

Means within the same row or column with different superscripts are significantly different. NS = Non-Significant SEM: Standard error of means.

\section{Blood Components}

Results of blood parameters presented in Table (4). Both tryptophan and threonine supplementation of experimental diets significantly differed, the concentration of total protein (TP), globulin (GOL) and $A / G$ ratio, while the interaction between them no effects on serum concentration of total protein. Supplementation of tryptophan, threonine, and interaction effects of them did not affect had no effect on albumin. Total cholesterol increased significantly with the different levels of dietary threonine, tryptophan and interaction between them. Threonine sup- plementation affected the blood serum concentrations of total cholesterol, whereas no effect on the concentrations of triglyceride. Tryptophan supplementation had no impact on the blood serum concentrations of total cholesterol and triglyceride.

These results are in harmony with those of Min et al (2017) and Corzo et al (2005), who found that tryptophan or threonine levels were affected in total protein and globulin levels. The effect on serum total protein is related to the increase of globulin and the enhancement of immune system function on chickens (Bovera et al 2016). The increase in protein and globulin due to the supplementation amino 
acids was reported to protect poultry against ammonia intoxication and oxidative stress (Tsiagbe et al 1987: Basiouni et al 2006; Bautista-Ortega et al 2013). However, serum triglyceride was not affected by tryptophan or threonine level, while serum cholesterol was significantly affected when threonine was supplemented. On the other hand, Attia et al (2001) reported that the supplementation of amino acids causes a reduction in serum total protein and an increase in serum triglycerides and cholesterol. Badinga et al (2003) and Aletor et al (2003) reported that amino acids play an important role in the metabolism of fat and cholesterol in poultry. Also, Mozhdeh et al (2010) reported that tryptophan supplementation significantly increased the concentration of total protein, albumin and uric acid at 27 and 49 days.

Table 4. Effect of feeding different levels of Threonine and Tryptophan on some blood parameters of broiler chicks

\begin{tabular}{|c|c|c|c|c|c|c|c|c|c|}
\hline \multirow{2}{*}{ Items } & \multirow{2}{*}{$\begin{array}{c}\text { Threonine } \\
\text { levels(T) }\end{array}$} & \multicolumn{3}{|c|}{ Tryptophan Levels (P) } & \multirow[t]{2}{*}{ Overall } & \multirow[t]{2}{*}{ SEM } & \multicolumn{3}{|c|}{ Prob } \\
\hline & & 100 & 150 & 200 & & & $\mathbf{T}$ & $\mathbf{P}$ & $T^{\star} \mathbf{P}$ \\
\hline \multirow{4}{*}{$\begin{array}{c}\text { Total protein } \\
\mathrm{g} / \mathrm{dL}\end{array}$} & 100 & 5.91 & 6.92 & 6.54 & $6.46^{a}$ & \multirow{4}{*}{0.32} & \multirow{4}{*}{$\star *$} & \multirow{4}{*}{ * } & \multirow{4}{*}{ NS } \\
\hline & 150 & 6.27 & 5.91 & 5.84 & $6.01^{b}$ & & & & \\
\hline & 200 & 5.79 & 6.17 & 5.93 & $5.96^{b}$ & & & & \\
\hline & Overall & 5.99 & 6.33 & 6.10 & & & & & \\
\hline \multirow{4}{*}{$\begin{array}{l}\text { Albumin g / } \\
\qquad \mathrm{dL}\end{array}$} & 100 & 4.19 & 3.38 & 4.02 & 3.86 & \multirow{4}{*}{0.66} & \multirow{4}{*}{ NS } & \multirow{4}{*}{ NS } & \multirow{4}{*}{ NS } \\
\hline & 150 & 4.09 & 3.89 & 3.92 & 3.96 & & & & \\
\hline & 200 & 4.14 & 3.96 & 4.03 & 4.04 & & & & \\
\hline & Overall & 4.14 & 3.74 & 3.99 & & & & & \\
\hline \multirow{4}{*}{$\begin{array}{c}\text { Globulin g / } \\
\text { dl }\end{array}$} & 100 & 1.71 & 3.54 & 2.52 & $2.59^{a}$ & \multirow{4}{*}{0.58} & \multirow{4}{*}{$\star *$} & \multirow{4}{*}{ * } & \multirow{4}{*}{ NS } \\
\hline & 150 & 2.18 & 2.01 & 1.92 & $2.04^{b}$ & & & & \\
\hline & 200 & 1.65 & 2.21 & 1.89 & $1.91^{b}$ & & & & \\
\hline & Overall & $1.85^{b}$ & $2.59^{a}$ & $2.11^{\mathrm{b}}$ & & & & & \\
\hline \multirow{4}{*}{$\mathrm{A} / \mathrm{G}$ ratio } & 100 & 2.45 & 0.95 & 1.60 & $1.49^{b}$ & \multirow{4}{*}{0.09} & \multirow{4}{*}{$* *$} & \multirow{4}{*}{ * } & \multirow{4}{*}{ NS } \\
\hline & 150 & 1.88 & 1.94 & 2.04 & $1.94^{\mathrm{a}}$ & & & & \\
\hline & 200 & 2.51 & 1.79 & 2.13 & $2.12^{\mathrm{a}}$ & & & & \\
\hline & Overall & $2.24^{a}$ & $1.44^{b}$ & $1.89^{b}$ & & & & & \\
\hline \multirow{4}{*}{$\begin{array}{c}\text { Cholesterol } \\
\mathrm{mg} / \mathrm{dl}\end{array}$} & 100 & 155.32 & 151.16 & 150.13 & $152.20^{b}$ & \multirow{4}{*}{8.27} & \multirow{4}{*}{$\star *$} & \multirow{4}{*}{ NS } & \multirow{4}{*}{ * } \\
\hline & 150 & 158.44 & 164.15 & 174.54 & $165.71^{a}$ & & & & \\
\hline & 200 & 158.44 & 158.44 & 157.40 & $158.09^{b}$ & & & & \\
\hline & Overall & 157.40 & 157.92 & 160.69 & & & & & \\
\hline & 100 & 184.47 & 188.06 & 184.47 & 185.67 & & & & \\
\hline Triglycerides & 150 & 183.88 & 183.8 & 181.49 & 183.08 & & $S$ & IS & $S$ \\
\hline $\mathrm{mg} / \mathrm{dl}$ & 200 & 180.29 & 182.6 & 147.46 & 170.15 & $27.0<$ & INS & INS & IVS \\
\hline & Overall & 182.89 & 184.88 & 171.14 & & & & & \\
\hline
\end{tabular}

Means within the same row or column with different superscripts are significantly different. NS = Non-Significant, SEM: Standard error of means.

\section{Carcass Characteristics}

Table (5) shown significantly differed in relative weights of carcass and edible parts related to the threonine amino acid effect. These percentages reduced significantly with increasing threonine level in the broiler diets, but tryptophan amino acid had not any significant effect on the above mentioned traits. This result may be explained by the fact that threonine caused an imbalance in amino acids that use in protein structure; also, the interaction between types and levels was not affected, this result agrees with Lisnahan and Nahak (2019). Percentages of giblets differed significantly related to tryptophan amino acids effect, where giblets weight percentage increases with increasing tryptophan, so the interaction between types and levels was affected. This result may be because the increase in amino acid caused an increasing in the muscular structure of gizzard and heart, but types of amino acids and 
Influence of dietary threonine and tryptophan supplementations on

broiler productivity traits under Egyptian summer conditions

Table 5. Effect of feeding different levels of Threonine and Tryptophan on carcass characteristics of broiler chicks

\begin{tabular}{|c|c|c|c|c|c|c|c|c|c|}
\hline \multirow[b]{2}{*}{ Traits } & \multirow[b]{2}{*}{$\begin{array}{c}\text { Threonine } \\
\text { levels(T) }\end{array}$} & \multicolumn{3}{|c|}{ Tryptophan Levels (P) } & \multirow[t]{2}{*}{ Overall } & \multirow[t]{2}{*}{ SEM } & \multicolumn{3}{|c|}{ Prob } \\
\hline & & 100 & 150 & 200 & & & $\mathbf{T}$ & $\mathbf{P}$ & $T^{\star} \mathbf{P}$ \\
\hline \multirow{4}{*}{ Carcass \% } & 100 & 71.60 & 71.19 & 71.34 & $71.37^{a}$ & \multirow{4}{*}{4.15} & \multirow{4}{*}{ ** } & \multirow{4}{*}{ NS } & \multirow{4}{*}{ NS } \\
\hline & 150 & 70.38 & 71.52 & 69.32 & $70.40^{b}$ & & & & \\
\hline & 200 & 69.95 & 69.77 & 70.29 & $70.01^{b}$ & & & & \\
\hline & Overall & 70.64 & 70.83 & 70.32 & & & & & \\
\hline \multirow{4}{*}{ Giblets \% } & 100 & 4.09 & 3.91 & 4.52 & 4.17 & \multirow{4}{*}{0.10} & \multirow{4}{*}{ NS } & \multirow{4}{*}{ * } & \multirow{4}{*}{ * } \\
\hline & 150 & 3.99 & 4.17 & 4.26 & 4.14 & & & & \\
\hline & 200 & 4.08 & 4.01 & 3.96 & 4.02 & & & & \\
\hline & Overall & $4.05^{b}$ & $4.03^{b}$ & $4.25^{a}$ & & & & & \\
\hline \multirow{4}{*}{$\begin{array}{c}\text { Edible parts } \\
\%\end{array}$} & 100 & 75.69 & 75.10 & 75.86 & $75.55^{a}$ & \multirow{4}{*}{0.51} & \multirow{4}{*}{ ** } & \multirow{4}{*}{ NS } & \multirow{4}{*}{ NS } \\
\hline & 150 & 74.37 & 75.70 & 73.58 & $74.55^{b}$ & & & & \\
\hline & 200 & 74.04 & 73.78 & 74.26 & $74.03^{b}$ & & & & \\
\hline & Overall & 74.70 & 74.86 & 74.57 & & & & & \\
\hline \multirow{4}{*}{ Liver \% } & 100 & 2.03 & 1.96 & 2.30 & 2.10 & \multirow{4}{*}{0.07} & \multirow{4}{*}{ NS } & \multirow{4}{*}{ * } & \multirow{4}{*}{ NS } \\
\hline & 150 & 2.04 & 2.29 & 2.39 & 2.24 & & & & \\
\hline & 200 & 2.15 & 2.19 & 2.15 & 2.17 & & & & \\
\hline & Overall & $2.08^{b}$ & $2.15^{\mathrm{b}}$ & $2.28^{a}$ & & & & & \\
\hline \multirow{4}{*}{ Gizzard \% } & 100 & 1.49 & 1.38 & 1.49 & $1.45^{a}$ & & & & \\
\hline & 150 & 1.44 & 1.33 & 1.28 & $1.35^{b}$ & & $* *$ & ** & \\
\hline & 200 & 1.40 & 1.29 & 1.21 & $1.30^{b}$ & 0.05 & $x \times$ & $x \times$ & NS \\
\hline & Overall & $1.44^{a}$ & $1.33^{b}$ & $1.33^{b}$ & & & & & \\
\hline & 100 & 0.44 & 0.39 & 0.52 & 0.45 & & & & \\
\hline Heart \% & 150 & 0.44 & 0.44 & 0.49 & 0.46 & כחת ח & NS & *** & NS \\
\hline & 200 & 0.42 & 0.44 & 0.47 & 0.44 & 0.02 & NS & $n$ & NS \\
\hline & Overall & $0.43^{b}$ & $0.42^{b}$ & $0.49^{a}$ & & & & & \\
\hline & 100 & 0.12 & 0.16 & 0.19 & $0.16^{a}$ & & & & \\
\hline & 150 & 0.05 & 0.10 & 0.08 & $0.08^{b}$ & & ** & ** & \\
\hline Spleen \% & 200 & 0.09 & 0.08 & 0.12 & $0.09^{b}$ & 0.01 & $x \times$ & $x \pi$ & NS \\
\hline & Overall & $0.09^{b}$ & $0.11^{\mathrm{ab}}$ & $0.13^{a}$ & & & & & \\
\hline & 100 & 0.14 & 0.15 & 0.22 & $0.17^{a}$ & & & & \\
\hline & 150 & 0.09 & 0.09 & 0.09 & $0.09^{b}$ & & $\star *$ & & \\
\hline Bursa \% & 200 & 0.12 & 0.09 & 0.09 & $0.10^{b}$ & 0.01 & $x^{x x}$ & NS & ** \\
\hline & Overall & 0.12 & 0.11 & 0.14 & & & & & \\
\hline
\end{tabular}

Means within the same row or column with different superscripts are significantly different. NS = Non-Significant SEM: Standard error of means.

threonine amino acid had not any significant effect on the percentage of giblets. Liver weight percentage differed significantly related to tryptophan amino acids effect, where it increased with increasing tryptophan levels in broiler diets, but threonine amino acid and the interaction between types and levels were not affected on the percentage of liver. The percentage of gizzard affected significantly related to both types of amino acids, where gizzard percentage reduced with increasing of both types of amino acids, but the interaction between types and levels was not affected. Percentage of heart differed significantly related to tryptophan amino acids effect, where this percentage increased with increasing tryptophan, but threonine levels and the interaction between types and levels were not affected. Spleen percentage decreased significantly with increasing threonine amino acid, but adding tryptophan in the diets significantly increased this percentage, but the interaction between types and levels was not affected. Bursa percentage was affected significantly by threonine level in diets where chicks fed $100 \%$ recorded highest bursa percentage 
$(0.17 \%)$, so the interaction between types and levels was affected, but chicks fed diets with tryptophan had not affected. David and Subalini (2015) whose found that feeding Tryptophan at the level of extra dietary $0.2 \%$, significantly increased dressing $\%$, liver $\%$, spleen $\%$, breast $\%$, thigh $\%$, shoulder $\%$ and left filet $\%$, while abdominal fat was significantly reduced with feeding Tryptophan. The improvement in carcass traits may be due to an increased amount of essential amino acids (Thr) in the diet (Estalkhzir et al 2013). Al-Hayani (2017) concluded that there was an increase in carcass weight by $3.7 \%$ and breast weight by $2.3 \%$ due to threonine supplementation, whereas there was a decrease in thigh weigh weight by $1.1 \%$. The improvement in carcass weight and quality may be related to the role of threonine on digestive enzymes function and intestinal mucosa development (Qaisrani et al 2018).

Conclusion: Results of the present study suggested that supplementation of threonine and tryptophan improve productive performance and carcass traits of broiler chicks without any adverse effects were found on blood components.

\section{REFERENCES}

A.O.A.C. 1990. Association of Official Analytical Chemists. Official Methods of Analysis, $15^{\text {th }}$ Ed., Washington, USA, Chapter 4, 1-25.

Abebe S. and Morris T.R. 1990. Effects of protein concentration on responses to dietary tryptophan by chicks. British Poultry Sci., 31(2), 267272.

Aletor V.A., Eder K., Becker K., Paulicks B.R., Roth F.X. and Roth-Maier D.A. 2003. The effects of conjugated linoleic acids or an alphaglucosidase inhibitor on tissue lipid concentrations and fatty acid composition of broiler chicks fed a low-protein diet. Poult Sci., 82, 796-804.

Al-Hayani W.K.A. 2017. Effect of Threonine Supplementation on Broiler Chicken Productivity Traits. Int. J. Poult. Sci., 16(4), 160-168.

Apoola E., Onimisi P.A., Ogundipe S.O. and Bawa G.S. 2017. Effect of dietary tryptophan levels on growth performance of broiler chickens reared in the hot season under tropical environment. Trop. Subtropical Agroecosyst., 20, 429-437.

Attia Y.A., Bohmer B.M. and Roth-Maier D.A. 2006. Responses of broiler chicks raised under constant relatively high ambient temperature to enzymes, amino acid supplementations, or diet density. Arch Geflug. 70, 80-91.
Azzam M., Dong X., Xie P. and Zou X. 2012. Influence of $L$-threonine supplementation on goblet cell numbers, histological structure and antioxidant enzyme activities of laying hens reared in a hot and humid climate. Br. Poult. Sci., 53, 640645.

Badinga L., Selberg K.T., Dinges A.C., Corner C.W., Miles R.D. 2003. Dietary conjugated linoleic acid alters hepatic lipid content and fatty acid composition in broiler chickens. Poult Sci., 82, 111-116.

Bai M., Liu H., Xu K., Oso A.O., Wu X., Liu G. and Yin Y. 2017. A review of the immunomodulatory role of dietary tryptophan in livestock and poultry. Amino Acids, 49, 67-74. https ://doi.org/10.1007/s00726-016-2351-8.

Barkley G. and Wallis I. 2001. Threonine requirements of broiler chickens: why do published values differ? Br. Poult. Sci., 42, 610-615.

Basiouni G., Najib H. and Zaki M.M. 2006. Influence of extra supplementation with arginine and lysine on overall performance, ovarian activities, and humoral immune response in local Saudi hens. Int J. Poult Sci., 5, 441-448.

Bautista-Ortega J., Ruiz-Feria J.N. and Stallone C.A. 2013. Effects of arginine and antioxidant vitamins on pulmonary artery reactivity to phenylephrine in the broiler chicken. Poult Sci., 92, 1062-1072.

Bovera F., Loponte R., Marono S., Piccolo G., Parisi G., laconisi V., Gasco L. and Nizza A. 2016. Use of Tenebrio molitor larvae meal as protein source in broiler diet: effect on growth performance, nutrient digestibility, and carcass and meat traits. J. Anim. Sci. 94, 639-647.

Campos A., Nogueira E., Albino L. and Rostagno H. 2010. Effects of digestible Tryptophan: Iysine ratios on performance and breast yield of broilers. Proceeding XIIIth European Poultry Conference, August 23-27, Tours, France. Poster Session I, $464 \mathrm{p}$.

Carlstedt I., Herrmann A., Karlsson H., Sheehan J., Fransson L. and Hansson G.C. 1993. Characterization of two different glycosylated domains from the insoluble mucin complex of rat small intestine. J. Biol. Chem. 268, 1877118781.

Chung T.K., Khajarern J. and Khajarern S. 1995. Effect of dietary threonine on growth performance and carcass characteristics of broiler chickens raised at high temperature. Singapore: Dept. of Animal Sci., Fac. of Agric., Khan Keen Univ., pp. 1-3. 
Corzo A, Kidd MT, Dozier WA, Pharr GT, and Koutsos E.A. 2007. Dietary threonine needs for growth and immunity of broilers raised under different litter conditions. J. of Applied Poultry Research; 16, 574-582.

Corzo A., Moran E.T.Jr., Hoehler D. and Lemmell A. 2005. Dietary tryptophan needs of broiler males from forty-two to fifty-six days of age. Poultry Sci., 84, 226-231.

David L.S. and Subalini E. 2015. Effects of feed restriction on growth performance, organ size and carcass characteristics of broiler chickens. Sch. J. Agric. Vet. Sci. 2, 108-111.

Dozier W.A., Moran E.T. and Kidd M.T. 2000. Threonine requirement of broiler males from 42 to $56 \mathrm{~d}$ in a summer environment. J. of Applied Poultry Research. 9, 496-500.

Duncan D.B. 1955. Multiple ranges and multiple $F$ tests. Biometrics, 11, 1-42.

Emadi, M., Kaveh, K. and Johnshiri, F. 2010. Dietary tryptophan effects on growth performance and blood parameters levels in broiler chicks. J. of Animal and Veterinary Advances 9, 700-704.

Estalkhzir F.M., Khojasteh S. and Jafari M. 2013. The effect of different levels of threonine on performance and carcass characteristics of broiler chickens. J. Novel Applied Sci., 2, 382-386.

Fatufe A.A., Hirche F. and Rodehutscord M. 2005. Estimates of individual factors of the tryptophan requirement based on protein and tryptophan accretion responses to increasing tryptophan supply in broiler chickens 8-1 days of age. Archives of Animal Nutrition, 59, 181-190. http://dx.doi.org/10.1080/17450390500147925.

Fernandez S.R., Aoyagi S., Han Y., Parsons C.M. and Baker D.H. 1994. Limiting order of amino acids in corn and soybean meal for growth of the chick. Poult. Sci., 73, 1887-1896.

Gogary M.R.E. and Azzam M.M. 2014. Effects of dietary tryptophan levels and stocking density during the growing-finishing phase on broiler performance and immunity. Asian J. Anim. Vet. Adv. 9, 568-577.

Harm R.H. and Russell G.B. 2000. Evaluation of tryptophan requirement of the commercial layer by using a corn-soyabean basal diet. Poultry Sci. J. 79, 740-742.

Hoseini S.M., Jiménez A.P., Costas B., Azeredo R. and Gesto M. 2019. Physiological roles of tryptophan in teleosts: current knowledge and perspectives for future studies. Rev. Aquacult., 11, 3-24.
Hsia L.C and Liao L.C. 2005. The effect of varying levels of tryptophan on growth performance and carcass characteristics of growing and finishing broilers. Asian Australasian J. of Animal Sci., 18(2), 230-234.

DOI: 10.5713/ajas.2005.230.

Kidd M. and Kerr B. 1996. L-threonine for poultry: A review. J. Appl. Poultry Res., 5, 358-367.

Lemme A. 2003. Reassessing amino acid levels for Pekin ducks. Poult Int. 42, 18-24.

Lisnahan C.V. and Oktovinas R.N. 2017. Effects of L-Threonine and L-Tryptophan Supplementation on Growth Performance of Native Chickens during the Grower Phase. Int. J. of Poultry Sci., 18, 570-575.

Martin C., Duclos M., Aguerre, S., Mormede P., Manier G. and Chaouloff F. 2000. Corticotropic and serotonergic responses to acute stress with/without prior exercise training in different rat strains. Acta Physiologica Scandinavica, 168, 421-430.

Min Y.N., Liu S.G., Qu Z.X., Meng G.H. and Gao Y.P. 2017. Effects of dietary threonine levels on growth performance, serum biochemical indexes, antioxidant capacities and gut morphology in broiler chickens. Poult. Sci., 96, 12901297.

Moghaddam H.S., Moghaddam H.N., Kermanshahi H., Mosavi A.H. and Raji A. 2011. The effect of threonine on mucin 2 gene expression, intestinal histology, and performance of broiler chicken. Italian J. of Animal Sci., 10, 66-70.

Mozhdeh E., Fatemeh J., Kamran K., Mohd H.B., Aini I. and Razak A. 2010. Tryptophan stimulates immune response in broiler chickens challenged with infectious bursal disease vaccine. J. of Animal and Veterinary Advances, 9, 610616.

Najafir., Ahmar R. and Tazehk G. 2017. Effect of different dietary threonine levels on optimal growth performance and intestinal morphology in 1-14 days old Ross 308 broilers. Braz. J. Poultry Sci., 19, 59-66.

NRC. 1994. Nutrient Requirements of Poultry. 9th Ed., National Academy Press, Washington, DC., USA., 155 p.

North M.O. 1981. Commercial chicken production manual. Avi publishing company. INC, West Port, Connecticut, USA, pp. 275-289.

Qaisrani S.N., Ahmed I., Azam F., Bibi F., Saima T.N. Pasha and Azam F. 2018. Threonine in broiler diets: An updated review. Ann. Anim. Sci., 18, 659-674. 
Rama Rao S.V., Raju M.V.L.N., Panda A.K., Poonam N.S., Moorthy O.K. and Srilatha T. 2011. Performance, carcass variables and immune responses in commercial broiler chicks fed graded concentrations of threonine in diet containing sub-optimal levels of protein. Animal Feed Sci. and Technology 169, 218-223.

Richard D.M., Dawes M.A., Mathias C.W., Acheson A., Hill-Kapturczak N. and Dougherty D.M. 2009. L-tryptophan: Basic metabolic functions, behavioral research, and therapeutic indications. Int. J. of Tryptophan Research, 2, S2129.

Rosa A.P., Pesti G.M., Edwards H.M. and Bakalli R.I. 2001. Threonine requirements of different broiler genotypes. Poultry Sci., 80, 1710-1717.

SAS 1998. Statistical Analysis System guide: (6 $6^{\text {th }}$ Ed.) Institute Inc. Cary. NC. USA.

Shan A.S., Sterling K.G. Pesti G.M. Bakalli R.I. Driver J.P. Kerr and Tejedor A.A. 2003. The influence of temperature on the threonine and tryptophan requirements of young broiler chicks. Poultry Sci., 82, 1154- 1162. http://dx.doi.org/10.1093/ps/82.7.1154.

Tabiri H.Y., Kan S., Kazuaki T., Masaaki T. and Yukio A. 2002. Effects of Heat Stress and Dietary Tryptophan on Performance and Plasma Amino Acid Concentrations of Broiler Chickens. Asian-Aust. J. Anim. Sci., 15(2), 247-253.

Trevisi P., Corrent E., Mazzoni M., Messori S., Priori D., Gherpelli Y., Simon - Giovanni A. and Bosi P. 2015. Effect of added dietary threonine on growth performance, health, immunity, and gastrointestinal function of weaning pigs with differing genetic susceptibility to Escherichia coli infection and challenged with $E$. coli K88ac. J. Anim. Physiol. Anim. Nutr., 99, 511520.

Tsiagbe V.K., Cook M.E., Harper A.E. and Sunde M.L. 1987. Enhanced immune responses in broiler chicks fed methionine-supplemented diets. Poult Sci., 66, 1147-1154.

Waldroup P.W., Jiang Q. and Fritts C.A. 2005. Effects of supplementing broiler diets low in crude protein with essential and nonessential amino acids. Int. J. Poult. Sci., 4, 425-431.

Xi P.B., Lin Y.C., Jiang Z.Y., Zheng C.T., Zhou G.L. and Jiang S.Q. 2009. Effects of dietary tryptophan level on growth performance, carcass traits, 160 whole body nutrients retention and hypothalamic serotonin concentration in Chinese color feathered chick aged from 43 to 63 days. Chinese J. of Animal Nutrition. 21, 137-145.

Wu G. 2009. Amino acids: metabolism, functions, and nutrition. Amino Acids. 37, 1-17.

Zaghari M., Zaefarian F. and Shivazad M. 2011. Standardized ileal digestible threonine requirements and its effects on performance and gut morphology of broiler chicks fed two levels of protein. J. of Agric. Sci. and Technology 13, 541-552. 
تأثير إضافة الثريونين والتريبتوفان في العلائق على الصفات الإنتاجية لكتاكيت اللحم تحت ظروف الصيف المصري

\author{
عمرو عادل هلال1" - فتحي عبد العظيم1 - هاني على ثابت1 - أحمد محمد الباز2 2

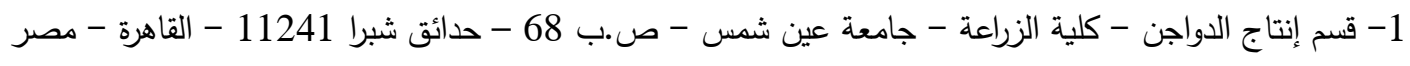

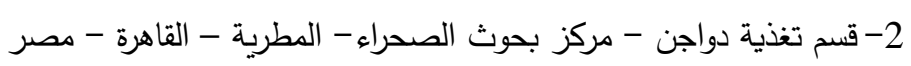

*Corresponding author: amradel2200@yahoo.com

Received 27 May, 2020

Accepted 23 August, 2020

عليقة تحتوي على 200٪ من الثريونين لديها تحسن في

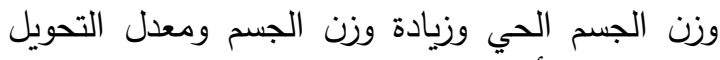
الغذائي مع أي من مستويات التربتوفان في علائق الجئ

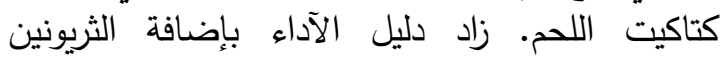
والتزيبتوفان في علائق بداري التسمين. تأثر تركيزات التئن

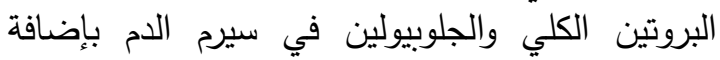

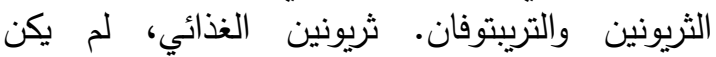

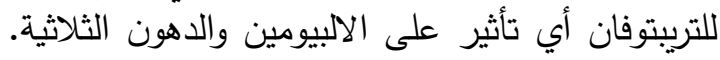

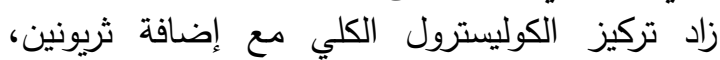

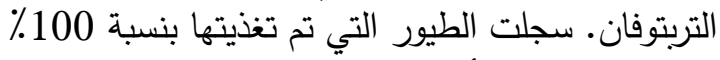
من الثريونين نتائج أفضل بشكل الطيون ملحوظ من تئن حيث الأوزان

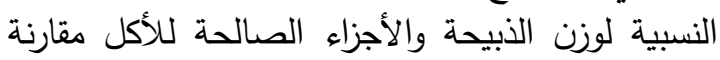

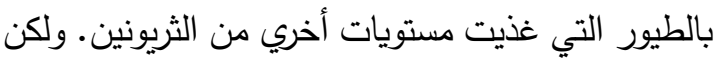

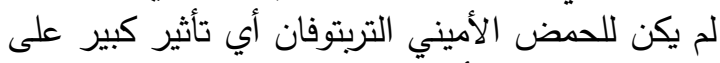

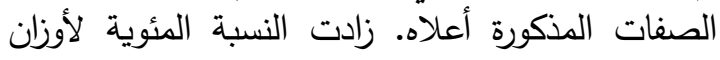

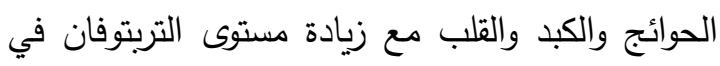

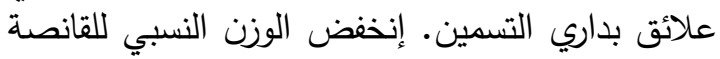
مع زيادة مستوى كل من الأحماض الأمينية في العلائق.

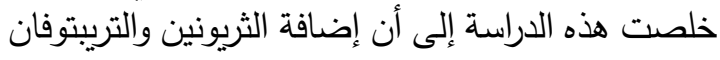

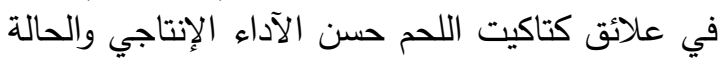

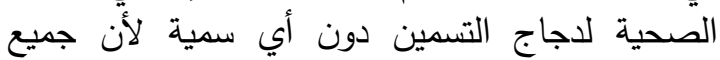
مكونات الدم التي تم قياسها كانت في المعدل الطبيعي.

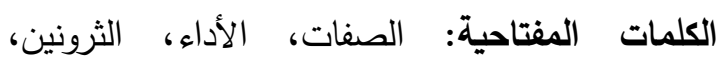
التريبتوفان، الدم، الذبيحة المنة 